【カテゴリーII】

\title{
高強度コンクリートの圧縮強度の確率分布に及ぼす試験機及び供試体の影響 EFFECT OF TESTING MACHINE AND SPECIMENS ON PROBABILITY DISTRIBUTION OF COMPRESSIVE STRENGTH OF HIGH STRENGTH CONCRETE
}

\author{
鈴木澄江*，栘田佳寛**，野口貴文***，陣内 浩**** \\ Sumie SUZUKI, Yoshihiro MASUDA, Takafumi NOGUCHI \\ and Hiroshi JINNAI
}

\begin{abstract}
This paper presents the experimental result of testing machine and specimens factor on probability distribution of compressive strength of high strength concrete. It is clarified that the peak value of distribution is higher than the mean value of strength in high strength concrete, even if according to the testing method on JIS A 1108.

It is clear that the peak of distribution is close to the mean value of strength and shape of probabiliry distribution is close to normal distribution, when both sides of the specimen are grinded.
\end{abstract}

Keywords: Testing machine, Flatness of specimen, Probability distribution, Peak value, Normal probabirity curve 試験機，供試体の平面度，確率分布，最頻値，正規分布

\section{1. はじめに}

JIS A 1108 （コンクリートの圧縮強度試験力法）に従って圧縮強 度試験を行った管理用円柱供試体あるいは構造体から採取したコア 供試体の圧縮強度の確率分布形状は、その強度レベルにより必ずし も正規分布を示さないことを先に報告"1. 2)した。それらの圧縮強度 を統計的に処理したところ、圧縮強度が高くなるとその確率分布形 状は正規分布とならず、最頻值が平均值よりも高くなることが多く なり、又、平均値よりも大幅に低い強度が出現する確率があること が確認された。そこで筆者らは、これらに影響する要因が、試験機 あるいは供試体の処理にあるのではないかと考光、試験機の JIS 適 合性（沙-ズ I ）及び供試体の両端面を研磨した場合（沙一メ゙ II 及び III）における圧縮強度の確率分布形状について検討を行った。

\section{2. 検討の内容}

\section{1 試験機に関する検討（沙 $-\pi^{+}$）}

試験機の剛性、球面座あるいは加圧板等が JIS に適合していない 場合、供試体の上面に水平力が作用したり、均等な压縮応力が伝えら れないため、供試体が早期に破壊してしまい強度低下が生じるわ゙。 そこで目標設計基準強度（Fc）200,400,600 及び $800 \mathrm{kgf} / \mathrm{cm}^{2}$ のコン
クリートを 16 機の圧縮強度試験機（A〜 P） を用いてラウンドロ ビン試験を実施した結果"゙について、試験機が JIS A 1108:2001の規 格に適合しているか否かに分け、圧縮強度の確率分布を統計的に解 析し、試験機の影響が圧縮強度の確率分布に及ぼす影響を確認する ことを目的とした。コンクリートに使用した材料は、普通ポルトラ ンドセメント、砂、砕石及び化学混和剤（AE 剤または高性能减水 凨）であり、物性等の詳細は既報の論文 ${ }^{51,7)}$ を参照されたい。目標 設計基準強度（Fc）、圧縮強度レベル（圧縮強度の平均值の範囲） 及び調合を表 -1 に、試験機の種類・性能に関する詳細、JIS A 1108 との適否を表一 2 に示す。なお、ここでは $10 \mathrm{kgf} / \mathrm{cm}^{2}$ を $1 \mathrm{~N} / \mathrm{mm}^{2}$ と換算して以下 SI 単位表示とする。圧縮強度試験用供試体 は、銅製型梊を用いて作製し、目標設計基準強度 $20 \mathrm{~N} / \mathrm{mm}^{2}$ の供試 体については、上面をキャッピング、40、60 及び $80 \mathrm{~N} / \mathrm{mm}^{2}$ の供試 体は上面を研磨処理とした。解析の検討対象とした圧縮強度試験結 果を表ー 3 に示す。試験材舲は28日とした。圧縮強度べルは、約 $40 \sim 100 \mathrm{~N} / \mathrm{mm}^{2}$ であった。これらの圧縮強度について、目標設計基 準強度別に JIS に適合する試験機を用いた場合（試験機数 5 機、 $\mathrm{n}=25$ ）と適合していない試験機を用いた場合（試験機数 11 機、 $\mathrm{n}=55)$ において、平均値からの偏差 $(\Delta \mathrm{X})$ 及び偏差を平均値で除

\footnotetext{
* 財建材試験センター中央試験所材料グループ 専門職 (宇都宮大学大学院工学研究科博士後期課程 生産・情報 工学専攻 大学院生)

** 宇都宮大学工学部建設学科 教授 · 工博

*** 東京大学大学院建築学専攻 助教授. 工博

**** 大成建設侏技術センター 主任研究員・博士 (工学)
}

Expert Official, Materials Testing Group, Central Laboratory, Japan Testing Center for Construction Materials

(Graduate Student, Department of Production and Imformation Science, Doctor's Degree Course, Graduate School of Engineering, Utsunomiya Univ.)

Prof., Dept. of Architecture and Civil Engineering, Faculty of Engineering, Utsunomiya Univ., Dr. Eng.

Assoc. Prof., Dept. of Architecture, Graduate School of Eng., The University of Tokyo, Dr. Eng.

Senior Research Engineer, Technology Center, Taisei Corp., Dr. Eng. 
表ー 1 コンクリートの圧縮強度レベル及び調合

\begin{tabular}{|c|c|c|c|c|c|c|}
\hline \multirow{2}{*}{$\begin{array}{l}\text { 目灀設計 } \\
\text { 基隻強度 } \\
\text { (Fc) } \mathrm{N} / \mathrm{mm}^{2}\end{array}$} & \multirow{2}{*}{$\begin{array}{c}\text { 圧樎強度の } \\
\text { 平均值の敕囲 } \\
\mathrm{N} / \mathrm{m}^{2}\end{array}$} & \multirow{2}{*}{$\begin{array}{c}\text { 水セx忆比 } \\
\% \\
\end{array}$} & \multicolumn{4}{|c|}{ 単位量 $\mathrm{kg} / \mathrm{m}^{3}$} \\
\hline & & & 水 & セメント & 耕骨材 & 粗骨材 \\
\hline 20 & $34.8 \sim 40.5$ & 60 & 185 & 308 & 793 & 999 \\
\hline 40 & $59.4 \sim 70.8$ & 40 & 170 & 425 & 746 & 1004 \\
\hline 60 & 74. $2 \sim 91.9$ & 32 & 160 & 500 & 710 & 1004 \\
\hline 80 & $95.2 \sim 118.0$ & 25 & 160 & 645 & 645 & 1004 \\
\hline
\end{tabular}

表 -2 試験機の種類・性能

\begin{tabular}{|c|c|c|c|c|c|c|c|}
\hline \multirow{2}{*}{ 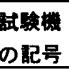 } & \multirow{2}{*}{$\begin{array}{c}\text { 最大粨魚 } \\
\text { tf }\end{array}$} & \multirow[t]{2}{*}{ 制御方法 } & \multirow{2}{*}{$\begin{array}{l}\text { 酯性 } \\
\mathrm{tf} / \mathrm{cm}\end{array}$} & \multirow{2}{*}{$\begin{array}{l}\text { 加圧板 } \\
\text { 寸法 } \mathrm{Cm}\end{array}$} & \multicolumn{2}{|c|}{ 球面座 cm } & \multirow{2}{*}{$\begin{array}{l}\text { JIS A1108 } \\
\text { ¿の通否 }\end{array}$} \\
\hline & & & & & 宜径 & 中心" & \\
\hline$A$ & 100 & 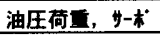 & 218 & $\phi 16$ & 16.6 & +0.7 & 否 \\
\hline$B$ & 200 & 油圧荷垔 & 440 & $\phi 21$ & 15.8 & +1.1 & 否 \\
\hline C & 100 & 油圧荷 $\mathbf{F}$ & 218 & $22 \times 22$ & 2.8 & +7.1 & 否 \\
\hline$D$ & 200 & ネジ式䘫位 & 635 & $30 \times 30$ & 24.1 & -0.2 & 否 \\
\hline$E$ & 100 & 油圧荷要 & 393 & $16 \times 16$ & 16.0 & \pm 0 & 遇 \\
\hline $\mathrm{F}$ & 100 & くさひ式変位 & 3100 & $\phi 22$ & 52.8 & -20.4 & 否 \\
\hline$G^{21}$ & 500 & 油圧荷青 & 707 & $\phi 15$ & 4.4 & +8.8 & 否 \\
\hline $\mathrm{H}$ & 100 & 油圧何重 & 453 & $\phi 16$ & 140 & \pm 0 & 道 \\
\hline 1 & 200 & 油圧荷 & 518 & $32 \times 32$ & 29.0 & \pm 0 & 道 \\
\hline $\mathrm{J}$ & 200 & 油圧荷 $\mathbf{Z}$ & 526 & $\phi 32$ & 29.0 & \pm 0 & 迺 \\
\hline $\mathrm{k}$ & 200 & 油圧荷酉， y-末 & 906 & $\phi 16$ & 15.0 & +0.5 & 否 \\
\hline $\mathrm{L}$ & 100 & 油圧荷亘 & 259 & $\phi 16$ & 12.6 & +1.8 & 否 \\
\hline$M$ & 400 & 油圧荷豆， & 20000 & $\phi 16$ & 240 & -6.0 & 丕 \\
\hline $\mathrm{N}$ & 100 & 油压荷 & 303 & $\phi 16$ & 3.2 & +5.3 & 否 \\
\hline 0 & 100 & 油圧荷 $\mathbf{R}$ & 356 & $\phi 23$ & 17.4 & \pm 0 & 道 \\
\hline$p$ & 200 & 油圧荷 & 442 & $\phi 32$ & 4.8 & +8.3 & 否 \\
\hline
\end{tabular}

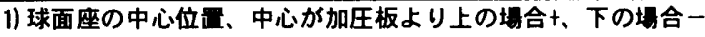

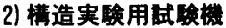

3) フレーム㓮性

して百分率（V(\%)）で表したもの（以下、これを変動率と呼ぶ） を求め、それらの分布により各圧縮強度レベルにおける武験機 （JIS の適否）による影響（バラツキ）を確認した。なお、偏差 ( $\Delta \mathrm{X})$ の求め方の詳細は、既報”で記述した。

\section{2 供試体に関する室内試験による検討（沙-ズ II)}

高強度コンクリートの圧縮強度試験では、強度武呀機の JIS 規格 に対する適合性とともに供試体の端面処理が重要であるといわれて いる。JIS A 1132 （コンクリートの強度試験用供武体の作り方）で は、供試体の載荷面の平面度を直径の $0.05 \%$ 以下と規定している が、高強度コンクリートの場合においては必ずしもこの精度で十分 とは考えられていない。そこで、供試体の両端面を適正に研磨処理 し圧縮強度試験を行った場合の強度分布に関する検討として、筆者 のうちの一人が 2003 年 2 月〜 7 月に行った高強度コンクリートの 実験 ${ }^{8)}$,9) で得られた圧縮強度試験結果（約 1500 個のデー夕）にもと づいて解析を行った。実験に使用した主な材料は、結合材として、 普通ポルトランドセメント（記号：OPC、密度 $3.16 \mathrm{~g} / \mathrm{cm}^{3}$ ) 、低熱 ポルトランドセメント（記号：LPC、密度 $3.22 \mathrm{~g} / \mathrm{cm}^{3}$ ) 及び高強度

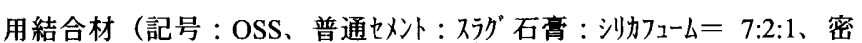
度 $2.99 \mathrm{~g} / \mathrm{cm}^{3}$ ) 、細骨材は大月産安山岩系研砂（密度 : $2.62 / \mathrm{cm}^{3}$ 、吸
表 -3 圧縮強度試験結果

\begin{tabular}{|c|c|c|c|c|c|c|c|c|c|}
\hline \multirow{2}{*}{$\begin{array}{c}\text { 試験㼄 } \\
\text { 䛶号号 }\end{array}$} & \multirow{2}{*}{$\begin{array}{l}\text { 番 } \\
\text { 号 }\end{array}$} & \multicolumn{2}{|c|}{$\mathrm{Fc}=20 \mathrm{~N} / \mathrm{mm}^{2}$} & \multicolumn{2}{|c|}{$\mathrm{Fc}=40 \mathrm{~N} / \mathrm{mm}^{2}$} & \multicolumn{2}{|c|}{$\mathrm{Fc}=60 \mathrm{~N} / \mathrm{mm}^{2}$} & \multicolumn{2}{|c|}{$F c=80 \mathrm{~N} / \mathrm{mm}^{2}$} \\
\hline & & 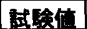 & 平均什 & 試医值 & 平均值 & 式駼值 & 平均值 & 試臨值 & 平均倠 \\
\hline \multirow{4}{*}{ A } & 1 & 38.5 & \multirow{4}{*}{ 38. 8} & 64.6 & \multirow{4}{*}{67.5} & 86.9 & & 111.5 & \\
\hline & 2 & 38.2 & & 67.5 & & 90.0 & & 102.9 & \\
\hline & 3 & 38.5 & & 68.3 & & 86.6 & 87.6 & 113.1 & 106.6 \\
\hline & $\frac{4}{5}$ & $\frac{39.1}{39.6}$ & & $\begin{array}{l}70.3 \\
66.8\end{array}$ & & 85.6 & & 112.2 & \\
\hline & $\frac{5}{1}$ & 36.8 & & 63.7 & & 82.3 & & 89.3 & \\
\hline & 2 & 36.7 & & 66.4 & & 85.5 & & 103.1 & \\
\hline B & 3 & 37.2 & 37. 2 & 64.7 & 66.4 & 79.5 & 82.0 & 105.1 & 98.0 \\
\hline & 4 & 36.9 & & 70.2 & & 78.0 & & 97.6 & \\
\hline & 5 & 38.4 & & 67.2 & & 84.9 & & 94.9 & \\
\hline & 1 & 31.4 & & 63.7 & & 71.9 & & 97.5 & \\
\hline C & $\frac{2}{3}$ & $\frac{30.1}{39.1}$ & 34.8 & $\frac{66.4}{64.7}$ & 600 & $\frac{78.9}{76.3}$ & 790 & 94.2 & 100 \\
\hline & 4 & 37.1 & & 70.2 & 00.0 & 85.5 & 19.0 & $\frac{99.2}{95.6}$ & 100.0 \\
\hline & 5 & 36.4 & & 67.2 & & 82.3 & & 113.7 & \\
\hline & 1 & 40.6 & & 73.9 & & 89.8 & & 107.3 & \\
\hline & 2 & 39.4 & & 56.1 & & 89.6 & & 113.3 & \\
\hline D & 3 & 41.8 & 40.5 & 71.3 & 68.7 & 92.5 & 91.9 & 116.9 & 115.0 \\
\hline & 4 & 41.6 & & 71.0 & & 96.5 & & 119.8 & \\
\hline & 5 & 39.3 & & 71.4 & & 91.3 & & 117.9 & \\
\hline & 1 & 39.6 & & 71.1 & & 89.7 & & 116.9 & \\
\hline & 2 & 38.4 & & 70.3 & & 92.5 & & 121.9 & \\
\hline E & 3 & 39.9 & 39.3 & 72.0 & 70.8 & 88.4 & 90.3 & 116.3 & 118.0 \\
\hline & 4 & 39.0 & & 71.1 & & 91.2 & & 116.7 & \\
\hline & 5 & 39.8 & & 69.7 & & 898 & & - & \\
\hline & $\frac{2}{1}$ & 37.0 & & 67.8 & & 85.6 & & 109.2 & \\
\hline & 2 & 35.8 & & 66.5 & & 83.9 & & 119.1 & \\
\hline$F$ & 3 & 37.4 & 36.2 & 64.8 & 65.5 & 75.1 & 82. 4 & 114.4 & 113.2 \\
\hline & 4 & 36.7 & & 61.9 & & 85.4 & & 108.5 & \\
\hline & 5 & 34.0 & & 66.7 & & 81.9 & & 114.7 & \\
\hline & 1 & 37.3 & & 66.2 & & 84.1 & & 84.1 & \\
\hline & $\frac{1}{2}$ & 38.0 & & $\begin{array}{l}\frac{0.02}{71.6} \\
\end{array}$ & & $\frac{04.1}{77.1}$ & & 90.2 & \\
\hline G & 3 & 39.6 & 3 8. 7 & 59.6 & 65.5 & 71.0 & 74.2 & 103.4 & 95.2 \\
\hline & 4 & 39.7 & & 63.7 & & 71.0 & & 95.5 & \\
\hline & 4 & 38.2 & & 63.8 & & 86.5 & & 111.6 & \\
\hline & $\frac{4}{5}$ & 39.0 & & 67.4 & & $\begin{array}{l}90.3 \\
90.3\end{array}$ & & 105.7 & \\
\hline & 1 & 35.8 & & 57.7 & & 83.7 & & 104.6 & \\
\hline & 2 & 32.9 & & 55.9 & & 82.7 & & 100.4 & \\
\hline$J$ & 3 & 33.6 & з з. 9 & 63.4 & 59.4 & 80.1 & 80.4 & 102.0 & 101.1 \\
\hline & 4 & 32.6 & & 59.7 & & 81.7 & & 100.0 & \\
\hline & 5 & 34.6 & & 60.4 & & 73.9 & & 98.6 & \\
\hline & 1 & 37.1 & & 66.0 & & 83.5 & & 110.8 & \\
\hline & $\frac{1}{2}$ & 39.6 & & 67.2 & & 84.3 & & 115.1 & \\
\hline K & 3 & 37.3 & 37.1 & 66.8 & 66.7 & 89.3 & 85.6 & 103.0 & 112.3 \\
\hline & 4 & 36.7 & & 65.1 & & 83.7 & & 117.1 & \\
\hline & 5 & 35.0 & & 68.2 & & 87.2 & & 115.7 & \\
\hline & 1 & 35.2 & & 69.2 & & 87.8 & & 115.0 & \\
\hline & 2 & 37.9 & & 68.7 & & 88.4 & & 106.9 & \\
\hline L & 3 & 39.0 & 37.3 & 65.3 & 68.1 & 88.8 & 86.3 & 109.9 & 111.8 \\
\hline & 4 & 37.0 & & 69.0 & & 84.5 & & 112.3 & \\
\hline & 5 & 37.4 & & 68.3 & & 82.0 & & 114.9 & \\
\hline & $\frac{5}{1}$ & 37.0 & & 65.1 & & 81.3 & & 110.4 & \\
\hline & 2 & 36.5 & & 68.2 & & 81.3 & & 113.1 & \\
\hline$M$ & $\frac{4}{3}$ & 36.3 & 36.3 & 60.4 & 65.9 & 92.0 & 84. 6 & 105.9 & 106.9 \\
\hline & 4 & 35.5 & & 66.1 & & 84.8 & & 102.9 & \\
\hline & 5 & 36.0 & & 64.1 & & 83.5 & & 102.0 & \\
\hline & 1 & 37.1 & & 63.8 & & 82.5 & & 107.5 & \\
\hline & 2 & 36.7 & & 68.0 & & 86.6 & & 114.1 & \\
\hline $\mathrm{N}$ & 3 & 36.7 & 36.5 & 68.0 & 66.2 & 79.1 & 82. 5 & 108.6 & 107.9 \\
\hline & 4 & 36.8 & & 67.9 & & 81.7 & & 105.3 & \\
\hline & 5 & 35.4 & & 63.4 & & 82.5 & & 104.2 & \\
\hline & 1 & 36.3 & & 71.2 & & 92.0 & & 120.2 & \\
\hline & 2 & 37.0 & & 65.5 & & 90.6 & & 119.6 & \\
\hline 0 & 3 & 36.5 & 37.2 & 69.2 & 67.3 & 81.3 & 88. 6 & 110.6 & 116.9 \\
\hline & 4 & 38.0 & & 63.5 & & 88.9 & & 119.3 & \\
\hline & 5 & 38.4 & & 67.2 & & 90.4 & & 114.7 & \\
\hline & \begin{tabular}{|l|}
1 \\
\end{tabular} & 37.6 & & 67.6 & & 88.6 & & 107.9 & \\
\hline & 2 & 38.6 & & 70.3 & & 87.6 & & 113.0 & \\
\hline$P$ & 3 & 370 & 379 & 704 & 693 & 861 & 860 & 1018 & 1103 \\
\hline & 4 & 38.4 & & 68.4 & & 83.5 & & 114.8 & \\
\hline & 5 & 38.0 & & 69.6 & & 84.0 & & 113.9 & \\
\hline
\end{tabular}

水率： $2.73 \%$ ）、粗骨材は大月産安山岩系砕石 $2005 \mathrm{~A}$ （密度： $2.66 \mathrm{~g} / \mathrm{cm}^{3}$ 、吸水率 : $2.28 \%$ ）、化学混和剤はポリカルボン酸系高性 能 AE 滅水剤である。実験は室内実験とし、供試体は JIS A 1132 に 従って鋼製型梊を用いて作製した。供試体はすべて両端面を研磨処 理した後、所定の材路において圧縮強度試験を行った。圧縮強度の 解析に用いたデー夕は、圧縮強度の平均值の範囲が $18.2 \sim$ $180.4 \mathrm{~N} / \mathrm{mm}^{2}$ のコンクリートである。解析検討の対象としたコンク

表ー4 供試体に関する室内試験による検討（沙-ズ II ）で対象としたコンクリート

\begin{tabular}{|c|c|c|c|c|c|}
\hline 結合材の種類 & $\begin{array}{c}\text { テータ数 } \\
n\end{array}$ & $\begin{array}{c}\text { 圧蛨強度の平均值の範囲 } \\
\mathrm{N} / \mathrm{mm}^{2}\end{array}$ & $\begin{array}{c}\text { 水結合材比の範囲 } \\
\%\end{array}$ & $\begin{array}{c}\text { 試験材齢 } \\
\text { 至 }\end{array}$ & 䖭生方法 \\
\hline $\begin{array}{c}\text { 普通ポルトランドセメント } \\
\text { (o P C) }\end{array}$ & 477 & $33.5 \sim 151.6$ & $20 \sim 40$ & $2 \sim 91$ & 標準水中 \\
\hline $\begin{array}{c}\text { 低熱ポルトランドセメント } \\
\text { (L P C ) }\end{array}$ & 471 & 18. $2 \sim 154.4$ & $20 \sim 40$ & $2 \sim 91$ & 封かん \\
\hline $\begin{array}{c}\text { 高強度用結合材 } \\
\text { (OS S ) }\end{array}$ & 636 & $31.7 \sim 180.4$ & $15 \sim 40$ & $2 \sim 91$ & 加熱 $\left(35 \sim 85^{\circ} \mathrm{C}\right)$ \\
\hline
\end{tabular}


リートの概要を表ー4に示す。なお、供試体の両端面を研磨処理し たため、供試体は高さ $190 \sim 197 \mathrm{~mm}$ の寸法で圧縮強度試験に供し た。供試体の直径と高さの比が 1.90 以下の場合には、補正俰数を 用いて圧縮強度を補正する（JIS A 1107）が、本報告においては、 供試体の高さがこの比をを满足していたため、強度補正は行わず、 得られた压縮強度の值を用いて確率分布を求めた。

解析は、結合材の種類ごとに得られた圧縮強度の值を養生、材柃 に保わらず、表 -5 の圧縮強度レベル（120 以上 $140 \mathrm{~N} / \mathrm{mm}^{2}$ 末満の 圧縮強度レベルまで）に区分した場合と結合材の種類を分けずに圧 縮強度レベル（全ての圧縮強度レベル、但し $140 \mathrm{~N} / \mathrm{mm}^{2}$ 以上 $160 \mathrm{~N} / \mathrm{mm}^{2}$ 末满及び $160 \mathrm{~N} / \mathrm{mm}^{2}$ 以上は母集団の関倸により、 $140 \mathrm{~N} / \mathrm{mm}^{2}$ 以上のレベルとしてまとめた）ごとに区分した場合につ いて平均值からの偏差 $(\Delta \mathrm{X})$ 及び変動率 $(\mathrm{V}(\%))$ を用いて行っ た。

\section{3 供試体に関する実機試験による検討（沙-ズ III）}

シリーズI と同様に筆者のうちの一人が、高強度コンクリートの 試験において供武体に関する検討の一環として実施した実機試験を もとに解析する。レディーミクストコンクリート工場において作製 した供試体の両端面研磨処理が圧縮強度の試験結果に及ぼす影響を 確認することを目的として、2 工場間（A 工場、B 工場）での比較 実験を行った。A 工場における使用材料は、普通ポルトランドセメ ント（密度 $3.16 \mathrm{~g} / \mathrm{cm}^{3}$ ) 、青海町産石灰岩系碎砂（表乾密度 $2.67 \mathrm{~g} / \mathrm{cm}^{3}$ ) 、能代市産山砂 (表乾密度 $2.59 \mathrm{~g} / \mathrm{cm}^{3}$ ) 、秋田県西木村 産碎石（表乾密度 $2.67 \mathrm{~g} / \mathrm{cm}^{3} 、$ 実積率 $61.4 \%$ ）及びポリカルボン酸 系高性能 A E 減水郕とした。B工場における使用材料は、普通ポル トランドセメント（密度 $3.16 \mathrm{~g} / \mathrm{cm}^{3}$ ) 、仙北郡産山砂（表乾密度 $2.60 \mathrm{~g} / \mathrm{cm}^{3}$ ) 、能代市産山砂 (表乾密度 $2.60 \mathrm{~g} / \mathrm{cm}^{3}$ ) 、秋田県西木村 産砕石（表乾密度 $2.66 \mathrm{~g} / \mathrm{cm}^{3} 、$ 実積率 $61.0 \%$ ）及びポリカルボン酸 系高性能 $\mathrm{AE}$ 滅水剤とした。 2 工場で 3 水準の水セメント比の調合 (目標スランプフロー $60 \mathrm{~cm}$, 目標空気量 $4.5 \%$, 単位水量 $175 \mathrm{~kg} / \mathrm{m}^{3}$ 、 単位粗骨材かさ容積 $0.55 \mathrm{~m}^{3} / \mathrm{m}^{3}$ ) について実機で練混ぜを行い、採 取した供試体の圧縮強度試験を実施した。解析の対象としたコンク リートの概要を表一6に示す。解析は、圧縮強度の試験デー夕（1

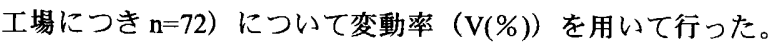

\section{3. 検討結果及び考察}

\section{1 試験機に関する検討（沙-ズ ）}

圧縮強度武験機が JIS に適合している場合と適合していない場合 とに分けて、圧縮強度試驗結果について、平均値からの偏差 $(\Delta$ X）の分布を図- 1 に示す。JIS に適合している試験機の場合、圧 縮強度の平均値の範囲が $80.4 \sim 90.3 \mathrm{~N} / \mathrm{mm}^{2}$ 及び $101.1 \sim$ $118.0 \mathrm{~N} / \mathrm{mm}^{2}$ では平均值からの偏差は、正規分布を示しておらず、 最頻値が平均値よりも高い側（+）に移行し、最大値と平均値の差 よりも平均値と最小値の差の方が大きくなる傾向を示している。ま
た、平均値からの偏差の分布範囲は、圧縮強度が高くなるほど大き くなることがわかる。一方、JIS に適合していない試験機の場合で は、圧縮強度の平均值の範囲が $60.0 \sim 69.3 \mathrm{~N} / \mathrm{mm}^{2}$ で最頻值が平均 值よりも高い側に分布し、平均値を大きく下回る強度が出現する分 布形状を示した。圧縮強度の平均值が $79.0 \sim 91.9 \mathrm{~N} / \mathrm{mm}^{2}$ 及び 95.2 〜 $115.0 \mathrm{~N} / \mathrm{mm}^{2}$ では、环縮強度が高くなるほど、平均值からの偏 差の分布幅が大きくなり、その分布幅は約 $\pm 15 \mathrm{~N} / \mathrm{mm}^{2}$ と JIS に適合 表 -5 結合材種類別の圧綟強度レベルとデータ数

\begin{tabular}{|c|c|c|c|}
\hline \multirow{2}{*}{ 圧樎強度レベル } & \multicolumn{3}{|c|}{ デー夕数 （個） } \\
\hline & OPC & $\mathrm{LPC}$ & OSS \\
\hline $60 \mathrm{~N} / \mathrm{mm}^{2}$ 末満 & 45 & 75 & 18 \\
\hline 60 以上 $80 \mathrm{~N} / \mathrm{mm}^{2}$ 末満 & 144 & 114 & 35 \\
\hline 80 以上 $100 \mathrm{~N} / \mathrm{mm}^{2}$ 末満 & 126 & 93 & 144 \\
\hline 100 以上 $120 \mathrm{~N} / \mathrm{mm}^{2}$ 末满 & 48 & 72 & 135 \\
\hline 120 以上 $140 \mathrm{~N} / \mathrm{mm}^{2}$ 末満 & 87 & 93 & 69 \\
\hline 140 以上 $160 \mathrm{~N} / \mathrm{mm}^{2}$ 未満 & 24 & 24 & 135 \\
\hline $160 \mathrm{~N} / \mathrm{mm}^{2}$ 以上 & - & - & 96 \\
\hline
\end{tabular}

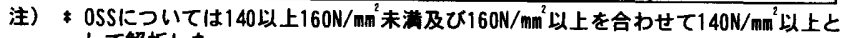
して解析した。
[J|Sに適合の試験機］
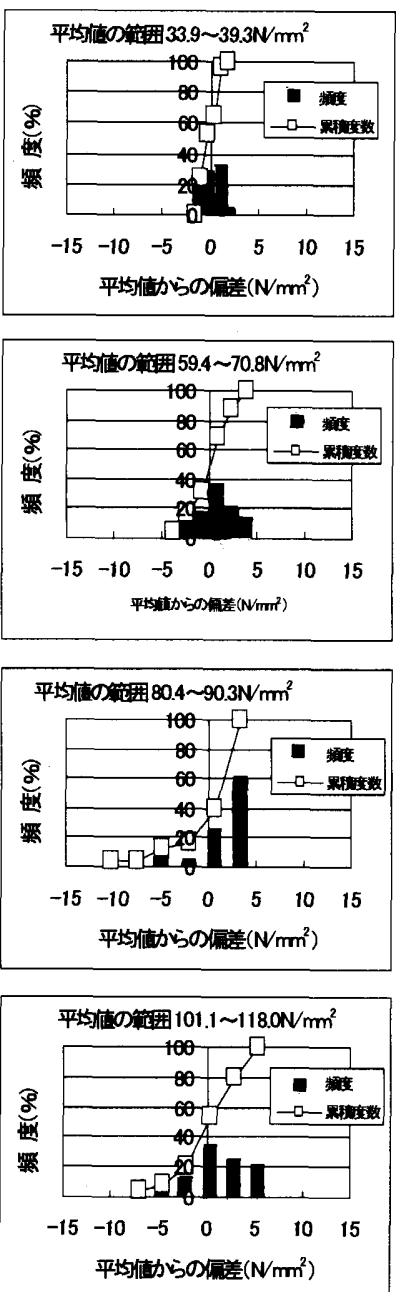

\section{[J|Sに不適合の試験機］}
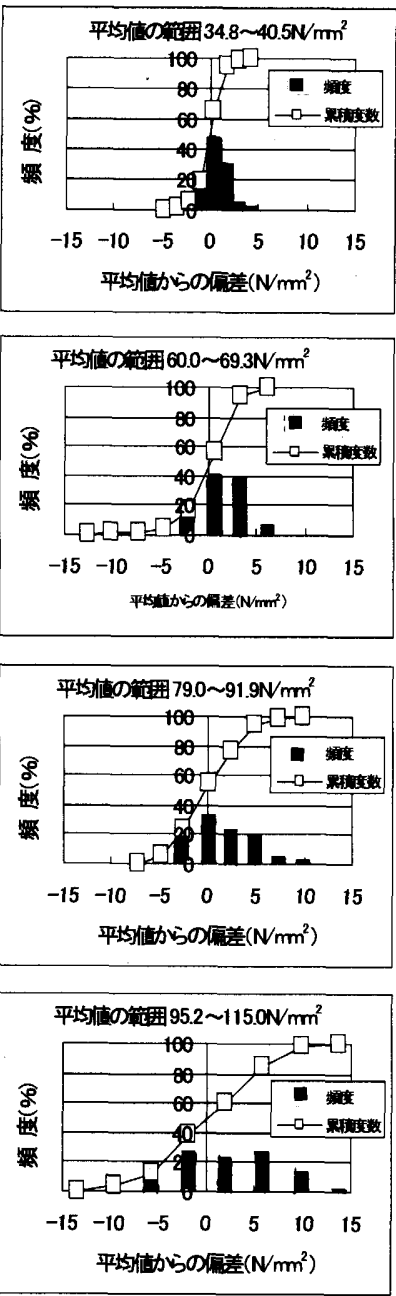

図-1 試験機のJIS適合否と平均値からの偏差 $(\Delta X)$ 表 -6 供試体に関する実機実験による検討（沙-ズ III）で対象としたコンクリート

\begin{tabular}{|c|c|c|c|c|c|c|}
\hline 工場区分 & $\begin{array}{c}\vec{\tau}-\text { 夕数 } \\
n\end{array}$ & $\begin{array}{c}\text { 圧蛨強度の平均值の範囲 } \\
\mathrm{N} / \mathrm{m}^{2}\end{array}$ & セメントの種類 & $\begin{array}{c}\text { 水セメント比の範围 } \\
\%\end{array}$ & $\begin{array}{c}\text { 尌験材秢 } \\
\quad \text { 日 }\end{array}$ & 養生方法 \\
\hline A工場 & 72 & 52. $5 \sim 111$ & \multirow{2}{*}{$\begin{array}{c}\text { 普通ポルトランド } \\
\text { セメント }\end{array}$} & \multirow{2}{*}{$25 \sim 35$} & \multirow{2}{*}{$7 \sim 91$} & \multirow{2}{*}{$\begin{array}{l}\text { 標準水中 } \\
\text { 埊断 }\end{array}$} \\
\hline B工場 & 72 & $48.6 \sim 83.9$ & & & & \\
\hline
\end{tabular}


している試験機を用いた場合の 2 倍となっている。

JIS に適合している試験機を用いた場合と適合していない試験機 を用いた場合の変動率（V(\%)）を図ー 2 に示す。JIS に適合してい る試験機を用いた場合と適合していない試験機を用いた場合の圧縮 強度の変動率を比較すると、JIS に適合している試験機では、変動 率の範囲が圧縮強度レベルにかかわらず、ほぼ一定であり、5\%程 度の值を示している。一方、JIS に適合していない試験機を用いた 場合には、圧縮強度レベルにかかわらず変動率の笧囲が $10 \sim 15 \%$ （最大で $20 \%$ ）と非常に大きくなることが確認された。

圧縮強度試験機の JIS 適合性と圧縮強度の確率分布形状を検討し た結果、試駼機の JIS との適否にかかわらず、圧縮強度が高くなる とその確率分布形状は正規分布から最頻值が平均値よりも高い方へ 移行する分布形状を示す結果となった。又、JIS に適合していない 試験機で圧縮強度試験を実施した場合は、平均値からの偏差の分布 幅が広くなり、適合している試験機の約 2 倍、変動率では最大で約 3 倍となり、圧縮強度のバラツキが大きくなることが認められる。 JIS に適合している試験機を用いることにより、供試体に均等な圧 縮力が作用し、適切に武験が行われることから、供武体が精緻に作 製されれば、圧縮強度のバラツキが小さくなるといえる。

\section{2 供試体に関する室内試験による検討（沙-ズ II）}

供試体に関する検封では、供試体の両端面を研磨処理した場合に おいて、結合材の種類（OPC,LPC,OSS）別に表-5に示した圧縮 強度レベル $\left(120 \sim 140 \mathrm{~N} / \mathrm{mm}^{2}\right.$ まで）ごとの確率分布として、圧縮 強度の平均值からの偏差 $(\Delta \mathrm{X})$ の分布求めた。図 -3 に各結合材 の種類ごとの圧縮強度レベル別の平均値からの偏差 $(\Delta \mathrm{X})$ を示 す。供試体の両端面を研磨処理した場合の圧縮強度の確率分布を強 度レベルごとにみると、結合材の種類にかかわらず同様の分布形状 を示した。分布の傾向は、両端面研磨をしていないシリーズ I の場 合よりもやや正規分布に近い分布形状を示しているものの、最頻値

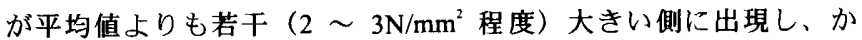
つ、平均值よりも大幅に低い強度が出現する確率が残されているこ とが確認できる。図ー 3 では $140 \mathrm{~N} / \mathrm{mm}^{2}$ までの圧縮強度レベルにお いて、その分布傾向を確認したが、压縮強度レベルが高い $100 \mathrm{~N} / \mathrm{mm}^{2}$ 以上では、平均值からの最大值及び最小值までの分布幅 で、最小値までの分布幅の方が $3 \sim 10 \mathrm{~N} / \mathrm{mm}^{2}$ 程度大きくなる傾向 を示した。結合材の種類で、確率分布形状に顥著な差が認められな かったことから、結合材の種類を分けずに、表一 5 に示す圧縮強度 レベルごとの変動率（V(\%)）を求め、図一 4 に示した。各圧縮強 度レベルにおける変動率の分布をみると、压縮強度レベルが高くな ると変動率は全体的に小さくなる傾向にあり、 $80 \mathrm{~N} / \mathrm{mm}^{2}$ 未満では 最大で $15 \%$ 程度、 80 以上 $140 \mathrm{~N} / \mathrm{mm}^{2}$ 未満では最大 $10 \%$ 程度であ る。一方、 $140 \mathrm{~N} / \mathrm{mm}^{2}$ 以上の圧縮強度レベルにおいては、変動率の 分布形状は正規分布を示し、その変動率は $5 \%$ と非常に小さい範囲 に収まっている。今回、140N/mm² 以上の圧縮強度レベルにおいて このような変動率に収まった要因は、供試体の整形がきわめて精緻 に行われたため、低い強度が出現しなかったことが推察される。 $80 \mathrm{~N} / \mathrm{mm}^{2}$ 未満で変動率が大きくなった原因は、標本対象としたデ 一夕の中に、3 個の供試体の個々のバラツキが大きいもの（3 個の うちの 1 個が大きくはずれている場合）が存在したためである。一
[J|Sに適合の試験機］
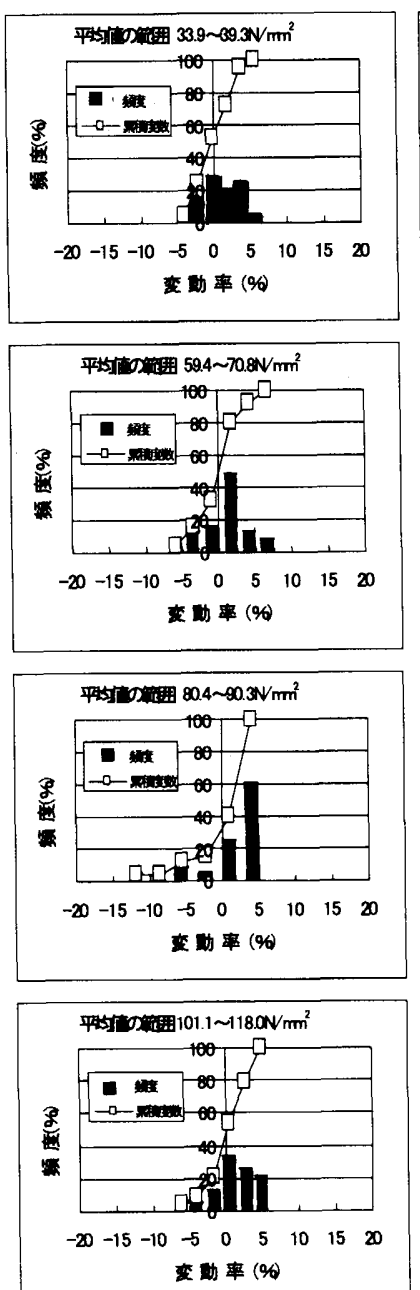

図一２試硂㙨のJIS適合否と変動率（V)
[J|Sに不適合の試験機］
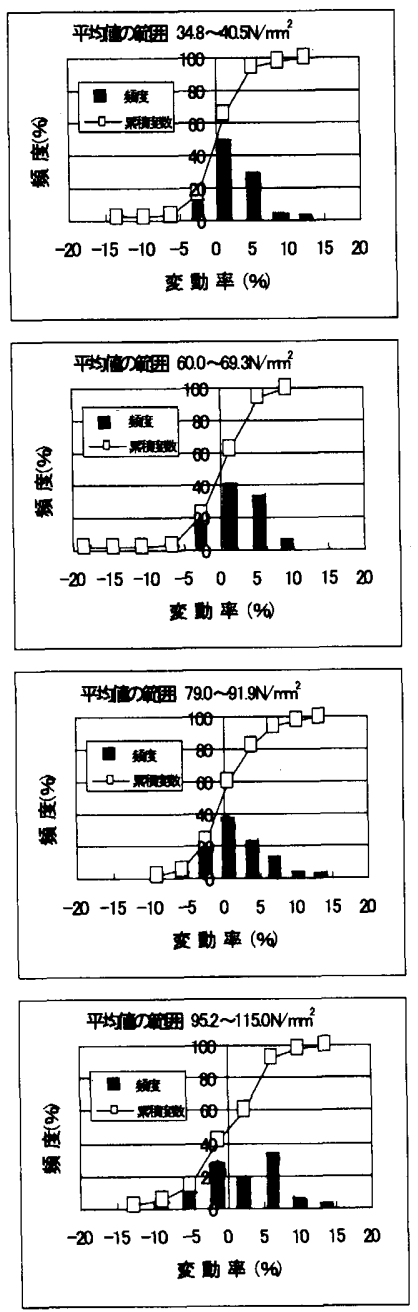

般には、実施工における3個平均のデー夕を標本とした設計基準強 度 $60 \mathrm{~N} / \mathrm{mm}^{2}$ 級のコンクリートの品質管理では、圧縮強度の変動係

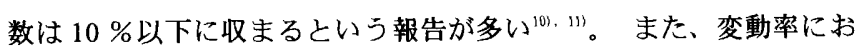
ける平均値と最頻值の関係をみると、最頻値は平均值よりも高い側 （+側）に出現していることが確認された。

これらの結果から、高強度コンクリートの圧縮強度試験を実施す る場合には、供武体の上下面を研磨処理することにより、JIS A 1132 に定められた平面度（直径の $0.05 \%$ 以内）よりも精度が高い 平面度が確保されるため、圧縮強度のバラツキが小さくなり圧縮強 度の確率分布形状が正規分布に近づく結果になったと考えられる。 但し、圧縮強度が高い領域の高強度コンクリートにおいては、最頻 值が平均値よりも若干 $\left(2 \sim 3 \mathrm{~N} / \mathrm{mm}^{2}\right)$ 、高い側（+側）に移行する傾 向があるが、全体的に変動率が小さくなる傾向があるといえよう。

\section{3 供試体に関する実機試験による検討（沙ーズ III）}

レディーミクストコンクリート工場における実機実験による検討 として、A及びBの 2 工場で実施した圧縮強度試験結果について、 変動率 $(\mathrm{V}(\%))$ を求め、その確率分布を図ー 5 に示した。

A工場では、全体としては矩形分布の形状を示した。一方、B工 場では、ほぼ正規分布に近い分布形状を示した。分布形状は工場に 


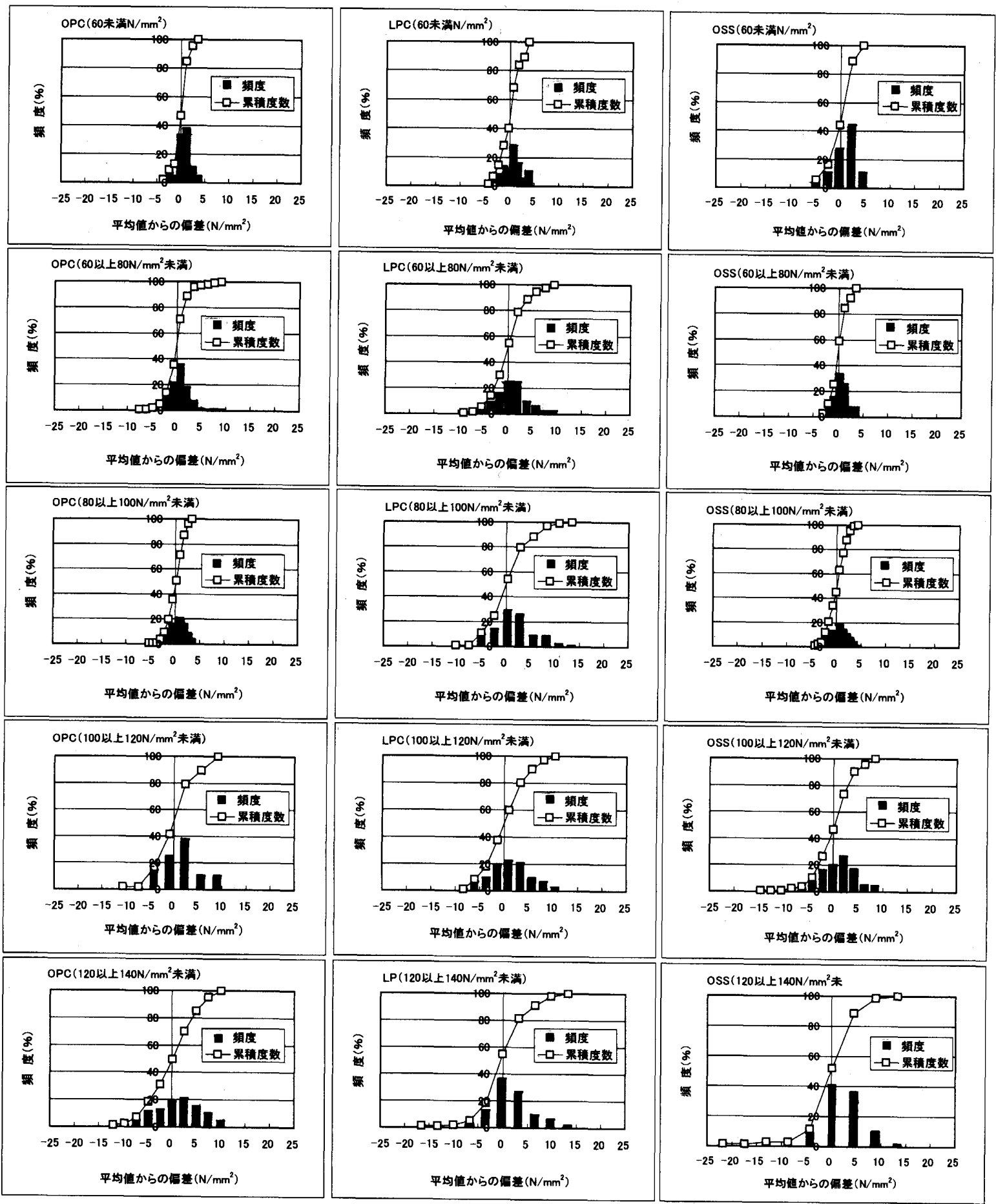

図-3 各結合材の種類ごとの圧縮強度レベル別の平均值からの偏差 $(\Delta \mathrm{X})$

より大きく異なるものの、いずれの工場においても、最頻値は若 干、平均値よりも大きい側（+側）に出現する傾向がみられ、実機 において採取した高強度コンクリートの管理用供武体の変動率が 5 \%程度に収まっている。両工場とも供試体の両端面を研磨処理して いることから、適切な供試体の載荷面処理が品質管理上有効である と考える。

\section{4. 結論}

試験機の JIS 適合性及び供試体の両端面を研磨処理した場合の高
強度コンクリートの圧縮強度試験において、压縮強度の確率分布を 検討した結果、本研究の範囲内で以下のことが明らかになった。

（1）圧縮強度試験機が JIS に適合しているか否にかかわらず、高強 度コンクリートでは、圧縮強度の確率分布は正規分布から、最頻值 が平均值よりも高い側に移行する形状になることが確認された。

また、JIS に適合していない試験機を用いた場合の平均值からの 偏差 $(\Delta \mathrm{X})$ の分布幅は、適合している試験機を用いた場合の約 2 倍であり、適合していない武験機を用いた場合には圧縮強度のバラ ツキが大きくなる。 

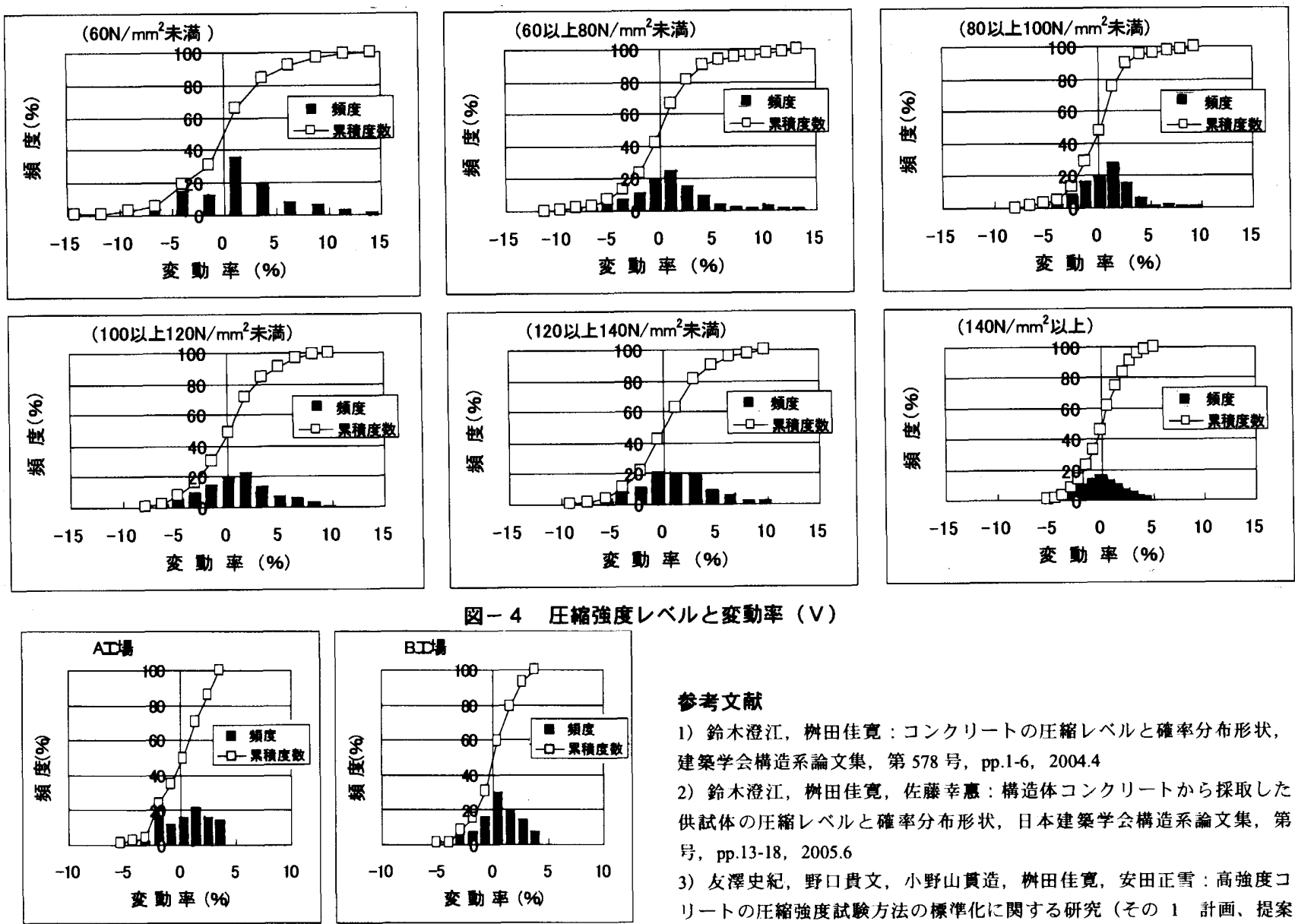

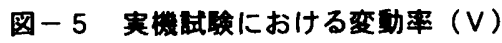

（2）JISに適合している圧縮強度試験機を用いた場合の圧縮強度試

験結果では、変動率 $(\mathrm{V}(\%))$ は圧縮強度レベルにかかわらず一定 であった。

（3）JISに適合していない压縮強度試験機を用いた場合の圧縮強度 武験結果では、JISに適合している圧縮強度試駼機を用いた場合に 比べ、変動率 $(\mathrm{V}(\%))$ は大きくなり、適合している武験機を用い た場合の約 3 倍の変動率を示した。

(4)供試体の両端面を研磨処理した場合には、压縮強度レベルにか かわらず、圧縮強度の確率分布形状は正規分布に近くなる結果を示 した。また、平均值からの偏差の分布幅及び変動率は、強度レベル が高い高強度コンクリートにおいても小さく、圧縮強度のバラツキ が小さく、試験精度の向上が見込める。

以上のことから、高強度コンクリートの圧縮強度試験結果は、最 頻值が平均値よりも若干高い側に移行するとともに、低い強度が出 現する可能性があるため、調合設計においては、正規偏差を大きく とることが望ましい。また、JIS に適合する試験機を用いて、供試 体を精繳に作製し、かつ、供試体の両端面を適切に研磨処理するこ とにより、バラツキを小さくすることが可能となるため、強度レベ ルが高い高強度コンクリートにおいても変動係数を小さく設定する ことが可能性であるといえる。

\section{考文献}

1）鈴木澄江，㨆田佳寛：コンクリートの圧樎レベルと確率分布形状，日本 建築学会構造系論文集, 第 578 号, pp.1-6, 2004.4

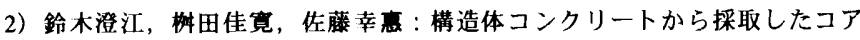
供試体の压縮レベルと確率分布形状，日本建築学会構造系論文集，第 592 号, pp.13-18, 2005.6

3）友澤史紀, 野口贯文, 小野山貫造, 䏧田佳寞, 安田正雪：高強度コンク リートの压䑿強度試験方法の標準化に関する研究（その 1 計画、提案、試 験機の狌の影霜)，日本建築学会大会学術講演梗概集（九州），A， pp.505-506, 1989.10

4）友澤史紀，野川貴文，小野山貫造，排田佳寛，安田正雪：高強度コンク リートの纴綰强度試験方法の標淮化に関する研究（その 2 加压板、供試体

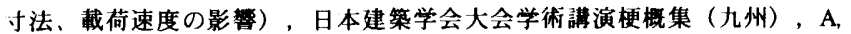
pp.507-508, 1989.10

5）友澤史紀，野口貴文，陳庭，枷田佳寛，阿部道彦，安田正雪：高強度コ ンクリートの圧綰強度試験方法の標準化に関する研究（その 4 試験機の影 整に関する共同試験：概要，試験機の調査，試験結果），日本建築学会大会 学術講演梗概集（中国），A，pp.449-500，1990.10

6）友㳯史紀, 野口貫文, 小野山貫造, 触田佳寞, 阿部道彦, 安田正雪：高 強度コンクリートの圧縮強度試験方法の標準化に関する研究（その 5 試馱 機の影繁に関する共同試験：分散分析，まとめ），日本建築学会大会学術講 演梗概集（中国），A，pp.501-502，1990.10

7）野口貴文：高強度コンクリートの基礎的力学特性に関する研究，学位論 文, 1995.3

8）陣内 浩, 桝田佳寛, 早川光敬：初期に高温履歴を受けた構造体コンク リートの簢易的な圧綰強度推定方法に関する研究, 日本建築学会構造系論文 集，第 579.号，pp.7-14，2004.5

9）陣内 浩: 高強度コンクリートの調合設計法の合理化に関する研究, 学 位論文, 2003.9

10）黑羽健闹，並木哲，河西正一，小林敏彦： $\mathrm{Fc} 600 \mathrm{kgf} / \mathrm{cm}^{2}$ の高強度コンク リートを用いた超高層建築物の施工，コンクリート工学, pp.29-39, Vol.33， No.9, 1995.9

11）並木哲：CFT 構造および高首 RC 造における品質管理の見状, コンクリ 一下工学, pp.52-55, Vol.39, No.5, 2001.5

(2005年 5 月 9 日原稿受理， 2005 年 9 月 13 日採用決定 